\title{
Root Diseases and Nematodes in Bahiagrass-Vegetable Rotations
}

\author{
D. R. Sumner, Department of Plant Pathology, University of Georgia; N. A. Minton, USDA/ARS (retired); T. B. \\ Brenneman, Department of Plant Pathology, University of Georgia; and G. W. Burton (retired) and A. W. John- \\ son, USDA/ARS, Coastal Plain Experiment Station, Tifton, GA 31793-0748
}

\begin{abstract}
Sumner, D. R., Minton, N. A., Brenneman, T. B., Burton, G. W., and Johnson, A. W. 1999. Root diseases and nematodes in bahiagrass-vegetable rotations. Plant Dis. 83:55-59.

A double-crop of cucumber-snap bean was grown continuously for 4 years and compared with rotations of 1,2, or 3 years of bahiagrass followed by vegetables. No nematicides or soil fungicides were applied. Root and hypocotyl disease severity in snap bean from Rhizoctonia solani AG-4 and Pythium spp. was decreased after 2 years of bahiagrass compared with 1 year of bahiagrass and 1 year of vegetables or continuous vegetables. Root galling caused by Meloidogyne incognita was less following 2 or 3 years, but not 1 year, of bahiagrass than following continuous vegetables. The beneficial effect of the rotation with bahiagrass lasted only 1 year. Then root injury from soilborne pathogenic fungi and root-knot nematodes was similar to that in continuous vegetables. Plant populations and yield of vegetables were greater following 3 years of bahiagrass than following 1 year of bahiagrass and 3 years of vegetables or continuous vegetables. Two years of bahiagrass followed by 1 or 2 years of vegetables did not increase yield of vegetables consistently.
\end{abstract}

Additional keywords: yellow nutsedge

Root diseases and plant-parasitic nematodes are limiting factors in vegetable production in the southeastern United States and many other subtropical and tropical areas of the world. Pathogenic fungi that may cause root and hypocotyl decay include Rhizoctonia solani, Pythium spp., Fusarium spp., and Sclerotium rolfsii $(27,28)$. The southern root-knot nematode (Meloidogyne incognita) is very destructive to plant roots of many vegetables and may reduce yield of vegetables considerably (14-16). Soil fungicides and nematicides available to control root pathogens are limited, and soil fumigation is expensive. Also, there are environmental concerns with soil pesticides, and many growers are looking for alternative methods of disease control.

Research with rotations of coastal bermudagrass (Cynodon dactylon) $(3,14,15)$, winter cover crops (29), and small grains (26) to reduce population densities of soilborne pathogens has been published. Rotations with bahiagrass (Paspalum notatum) have been evaluated for reduction of root injury by nematodes in agronomic crops $(1,2,4,17-21)$, fruit crops (6), and vegeta-

Corresponding author: D. R. Sumner

E-mail: path2@tifton.cpes.peachnet.edu

Accepted for publication 5 October 1998.

Publication no. D-1998-1026-01R

This article is in the public domain and not copyrightable. It may be freely reprinted with customary crediting of the source. The American Phytopathological Society, 1999. bles (5), but little research has been done on the influence of bahiagrass on the inoculum potential of soilborne pathogenic fungi in vegetables (10). There is the potential for increased crop loss if roots are infected with both plant-parasitic nematodes and soilborne pathogenic fungi.

Bahiagrass is commonly grown for livestock grazing and hay production in the southeastern United States. Tifton 9 is an improved cultivar of Pensacola bahiagrass with improved seedling vigor, and it produces more seed and forage than Pensacola (2). The objective of this research was to determine the long-term influence of Tifton 9 bahiagrass rotations on population densities of soilborne pathogenic fungi and nematodes and root diseases of vegetables.

\section{MATERIALS AND METHODS}

Experimental design and treatments. The research was done at the Coastal Plain Experiment Station Blackshank Farm on Tifton loamy sand soil (fine-loamy, siliceous, thermic Plinthic Kandiudults), $\mathrm{pH}$ 6.2, <1\% organic matter. Peanut (Arachis hypogaea) was grown in the field the year before the experiment, and lupines (Lupinus spp.) and pearl millet (Pennisetum glaucum) were grown in previous years. The experimental design was a randomized complete block with five replications. Plots were $7.6 \times 5.5 \mathrm{~m}$ and contained three raised beds on $1.8-\mathrm{m}$ centers. The treatments were crop rotations of vegetables (V) (cucumber [Cucumis sativus 'Comet'] and snap bean [Phaseolus vulgaris 'Strike']) and Pensacola bahiagrass (Pensacola notatum 'Tifton 9') (B) initi- ated in 1990 and continued for 4 years. The specific rotations were $\mathrm{V}-\mathrm{V}-\mathrm{V}-\mathrm{V}, \mathrm{B}-\mathrm{V}-\mathrm{V}-\mathrm{V}$, $\mathrm{B}-\mathrm{B}-\mathrm{V}-\mathrm{V}$, and B-B-B-V. All cultivars of cucumber are susceptible to $M$. incognita (13). The cultivar of snap bean used was susceptible to $M$. incognita, but some snap bean cultivars are resistant to $M$. incognita (14). Bahiagrass is a nonhost for several species of root-knot nematodes, including $M$. incognita and $M$. arenaria $(2,4,20)$.

Bahiagrass was seeded at $22.4 \mathrm{~kg} / \mathrm{ha}$ on 22 March 1990. Cultural practices were described previously (2). The thick residues in plots of bahiagrass were burned in the late winter before the initiation of new growth. Each year, soil was disk-harrowed and turned 20 to $25 \mathrm{~cm}$ deep with a moldboard plow in March or April in all plots to be planted with vegetables. A complete fertilizer (33.6, 67.2, 134.4, 60.5, and 47 $\mathrm{kg} / \mathrm{ha}$ of $\mathrm{N}, \mathrm{P}_{2} \mathrm{O}_{5}, \mathrm{~K}_{2} \mathrm{O}, \mathrm{Ca}$, and $\mathrm{S}$, respectively) was incorporated with a tractorpowered rotary tiller. In mid-April or early May of each year, cucumber was direct seeded 1.5 to $2 \mathrm{~cm}$ deep in a single row per bed, 3 to 4 seeds per hill in hills spaced 30 to $45 \mathrm{~cm}$ apart. Ethalfluralin and sethoxydim were applied for weed control, sevin and endosulfan for insect control, and mancozeb and triadimefon for late season control of foliage diseases. All pesticides were applied at recommended rates. $\mathrm{Cu}$ cumbers were harvested and graded by hand twice a week six to nine times each year. Fruits with lesions were selected empirically, surface-disinfested for 1 to 2 min in $0.5 \% \mathrm{NaOCl}$, and tissue sections 5 to $10 \mathrm{~mm}$ in diameter were removed (without rinsing) from the edges of lesions and incubated on water agar. Hyphal tips were transferred to potato dextrose agar (PDA), and the fungi were identified.

Cucumber vines were disk-harrowed in July and again in early August, and soil was turned 20 to $25 \mathrm{~cm}$ deep with a moldboard plow. Ammonium nitrate (168 $\mathrm{kg} / \mathrm{ha}$ ) was spread on the plots and incorporated $15 \mathrm{~cm}$ deep with a tractorpowered rotary tiller that prepared raised beds, and snap bean was planted 12 to 23 August each year. Seeds (65 kg/ha) were planted 2.5 to $4.0 \mathrm{~cm}$ deep, $5 \mathrm{~cm}$ apart in two rows per bed $91 \mathrm{~cm}$ apart. After planting, diazinon granules $(14 \mathrm{G}, 1.1 \mathrm{~kg}$ a.i./ha) were spread in a band $15 \mathrm{~cm}$ wide over the row to prevent injury from soil insects, and chlorthal-dimethyl was applied for weed control. In 1994, metolachlor was incorporated before planting to suppress yellow nutsedge (Cyperus esculentus). 
Snap bean plants in three $30-\mathrm{cm}$ sections of row in each row adjacent to the harvest bed were dug, washed, and rated for symptoms of root and hypocotyl discoloration and decay 2 to 3 weeks after planting. Plants were grouped into categories as follows: none $=\langle 2 \%$, slight $=2$ to $10 \%$, moderate $=11$ to $50 \%$, severe $=$ $>50 \%$ root and hypocotyl discoloration and decay, and dead or dying plants.

Plants were side-dressed with $37 \mathrm{~kg}$ of $\mathrm{N}$ per ha 3 to 4 weeks after planting and with $34 \mathrm{~kg}$ each of $\mathrm{N}$ and $\mathrm{K}_{2} \mathrm{O}$ per ha 2 weeks later. Mechanical cultivation and sethoxydim were used for midseason weed control. Acephate or fenvalerate was applied to prevent injury from foliar insects, and chlorothalonil for prevention of lateseason leaf spots and pod rots. All pesticides were applied at recommended rates. Green pods for fresh market were harvested by hand once or twice in October each year. Plots then were left in no till fallow until soil was prepared for cucumber in late March the following year.

Soil assays. In April and August or September of each year, 10 soil cores (2.5 $\mathrm{cm}$ diameter, $15 \mathrm{~cm}$ deep) were collected in each plot for quantification of soil fungi. Samples were mixed and stored at 6 to $8^{\circ} \mathrm{C}$ until processed in 1 to 8 weeks. Soil was assayed for $R$. solani AG-4, Rhizoctonia spp., and other basidiomycetes on tannic acid-benomyl agar (24) with a multiplepellet soil sampler (9), and for Pythium spp. on P5ARP agar (11). At each sampling, 10 colonies were transferred from soil dilutions on P5ARP agar and identified to species.

Soil was assayed for $M$. incognita on 10 April, 6 July, and 29 October 1990; 18
April, 26 June, and 10 December 1991; 17 March, 14 July, and 3 September 1992; and 20 April, 16 July, and 27 September 1993. Twenty soil cores $(2.5 \mathrm{~cm}$ diameter, $25 \mathrm{~cm}$ deep) were collected from each plot and mixed thoroughly. A $150 \mathrm{~cm}^{3}$ subsample was processed by centrifugal flotation (12). After the final harvest of cucumber and snap bean, 20 plants were dug from each plot and rated for the percentage roots galled by $M$. incognita on a 1 to 5 scale: 1 $=$ no galling, $2=1$ to $25,3=26$ to $50,4=$ 51 to 75 , and $5=76$ to $100 \%$.

Data analysis. Data were analyzed by PROC GLM and PROC STEPWISE statistical analysis programs (22). Fisher's least significant difference was used for means separation. Data were transformed as necessary for statistical analysis (square root transformations for small numbers [less than 100], log 10 for large numbers [greater than 100], or arcsine transformations for percentages) (23), but all data are reported as nontransformed values.

\section{RESULTS}

Seedling diseases and stand establishment. The primary fungi isolated from 46 dying cucumber seedlings the first year were Pythium aphanidermatum (24\%), Pythium spp. (13\%), Fusarium solani (11\%), and $R$. solani AG-4 (9\%). Postemergence damping-off was low in later years, and isolations were not made from dying seedlings. There were no differences in plant stands in cucumber following 1 or 2 years of bahiagrass compared with continuous vegetables, but in the fourth year, there were more plants following 3 years of bahiagrass than following 2 or 3 years of continuous vegetables $(P \leq 0.05)$ (Table $1)$. Postemergence damping-off averaged $26,13,18$, and $4 \%$ in cucumber during 1990 through 1993, respectively. In 1993, plant stands were poor in all plots primarily because of preemergence damping-off.

Postemergence damping-off was much greater in snap bean than in cucumber and averaged 21, 72, 49, and 39\% from 1990 through 1993, respectively. There were no significant differences in postemergence damping-off among rotations. One or 2 years of bahiagrass in rotation did not increase plant stands of snap bean compared with continuous vegetables, but snap bean stands were greater in the fourth year following 3 years of bahiagrass than in the other three rotations (Table $1, P=0.05$ ). The percentage of snap bean plants with severe $(>50 \%)$ root and hypocotyl discoloration and decay averaged 33,75 , and $44 \%$ from 1990 to 1992, respectively. Plants were inadvertently not rated in 1993. In 1992, snap bean following B-B had significantly $(P=0.05)$ fewer plants with severe root and hypocotyl discoloration and decay than did snap bean following $\mathrm{B}-\mathrm{V}$ or $\mathrm{V}-\mathrm{V}(23,52$, and $57 \%$, respectively). There were no significant differences among rotations in 1991. Fungi were isolated from 15 to 54 dying seedlings each year, and P. myriotylum (34\%) and $R$. solani $(23 \%)$ were isolated most frequently. Fusarium solani, F. oxysporum, Macrophomina phaseolina, and a sterile white basidiomycete were isolated less frequently.

Fruit and pod rots. The number of cucumber fruit with decay averaged 8.0, 11.4, 0.5 , and $4.6 \%$ from 1990 through 1993,

Table 1. Survival of cucumber and snap bean plants in vegetable-bahiagrass rotations, 1990 to $1993^{\mathrm{w}}$

\begin{tabular}{|c|c|c|c|c|c|c|c|c|}
\hline \multirow[b]{2}{*}{ Rotation $^{x}$} & \multicolumn{2}{|c|}{1990} & \multicolumn{2}{|c|}{1991} & \multicolumn{2}{|c|}{1992} & \multicolumn{2}{|c|}{1993} \\
\hline & $\mathrm{Cuc}^{\mathrm{y}}$ & $\mathbf{S B}^{\mathbf{y}}$ & Cuc & SB & Cuc & SB & Cuc & SB \\
\hline $\mathrm{V}-\mathrm{V}-\mathrm{V}-\mathrm{V}$ & 2.6 & 14.6 & 3.0 & 2.1 & 5.7 & 4.7 & $1.0 \mathrm{bc}$ & $2.9 \mathrm{~b}$ \\
\hline B-V-V-V & $\ldots$ & $\ldots$ & 3.5 & 1.8 & 6.6 & 7.1 & $0.6 c^{z}$ & $2.7 \mathrm{~b}$ \\
\hline B-B-V-V & $\ldots$ & $\ldots$ & $\ldots$ & $\ldots$ & 5.4 & 9.1 & $1.2 \mathrm{ab}$ & $3.1 \mathrm{~b}$ \\
\hline B-B-B-V & $\ldots$ & $\ldots$ & $\ldots$ & $\ldots$ & $\ldots$ & $\ldots$ & $1.6 \mathrm{a}$ & $6.1 \mathrm{a}$ \\
\hline
\end{tabular}

${ }^{w}$ Plants per $\mathrm{m}$ of row 3 to 5 weeks after planting.

${ }^{x} \mathrm{~V}=$ vegetables, $\mathrm{B}=$ bahiagrass. Each entry separated by a hyphen denotes a 1-year period.

${ }^{\mathrm{y}} \mathrm{Cuc}=$ cucumber, $\mathrm{SB}=$ snap bean.

${ }^{\mathrm{z}}$ Numbers within columns followed by the same letter are not significantly different according to $t$ tests (Fisher's LSD), $P=0.05$. No letters indicates no significant differences.

Table 2. Population densities of Rhizoctonia solani in soil in vegetable rotations with bahiagrass, 1990 to $1993^{\mathrm{v}}$

\begin{tabular}{|c|c|c|c|c|c|c|c|c|}
\hline \multirow[b]{2}{*}{ Rotationw } & \multicolumn{2}{|c|}{1990} & \multicolumn{2}{|c|}{1991} & \multicolumn{2}{|c|}{1992} & \multicolumn{2}{|c|}{1993} \\
\hline & $2 A p r^{X}$ & $21 \operatorname{Sept}^{\mathrm{y}}$ & 8 Apr $^{\mathrm{X}}$ & 14 Augy $^{y}$ & $3 \mathbf{A p r}^{\mathbf{x}}$ & 20 Augy & $30 \mathrm{Apr}^{\mathrm{x}}$ & 23 Augy $^{\mathrm{y}}$ \\
\hline V-V-V-V & 0 & $2.3 \mathrm{a}$ & $2.6 \mathrm{a}$ & 1.2 & 0 & 4.3 & 0 & 0 \\
\hline B-V-V-V & 0 & $0 \mathrm{~b}^{\mathrm{z}}$ & $0 \mathrm{~b}$ & 0 & 0 & 0 & 0 & 11.9 \\
\hline B-B-V-V & 0 & $0 \mathrm{~b}$ & $0 \mathrm{~b}$ & $\ldots$ & 0 & 4.3 & 0 & 1.3 \\
\hline B-B-B-V & 0 & $0 \mathrm{~b}$ & $0 \mathrm{~b}$ & $\ldots$ & 0 & $\ldots$ & 0 & 6.6 \\
\hline
\end{tabular}

${ }^{v}$ Colony-forming units (CFU)/100 g of oven-dried soil. Detection level varied from 1.5 to $2.0 \mathrm{CFU} / 100 \mathrm{~g}$ per treatment.

${ }^{\mathrm{w}} \mathrm{V}=$ vegetables, $\mathrm{B}=$ bahiagrass. Each entry separated by a hyphen denotes a 1-year period.

${ }^{x}$ Samples taken in April were after disk-harrowing and inverting topsoil with a moldboard turning plow in vegetables, or in bahiagrass sod.

${ }^{y}$ Samples were taken in the row after planting snap bean, or in bahiagrass sod. Samples were not taken in bahiagrass sod in 1991 and 1992.

${ }^{\mathrm{z}}$ Numbers in columns followed by the same letter are not significantly different according to $t$ tests (Fisher's LSD), $P=0.05$. No letters indicates no significant differences. 
respectively, and was not different among rotations. The primary symptoms on decayed fruit were reddish brown, sunken cankers typical of Rhizoctonia fruit rot, and $R$. solani AG-4 was the primary fungus isolated (4-year average, 46\%). Other fungi isolated included Fusarium spp. (22\%), P. aphanidermatum (5\%), and other Pythium spp. (4\%). The number of snap bean pods with lesions was $<0.5 \%$ each year.

Population densities of soil fungi. Population densities of $R$. solani AG-4 were below detection threshold levels (6 CFU/100 $\mathrm{g}$ of oven-dried soil) in all plots after plowing in April 1990. In contrast, the fungus was detected at low densities (average 2.3 and 2.6 CFU/100 g) in soil in continuous vegetables in September 1990 and April 1991, respectively. Those densities were greater than the nondetectable densities in bahiagrass (Table 2, $P=0.05$ ). In 1992 and 1993, densities were erratic and varied from nondetectable to 11.9 CFU/100 g, and there were no significant differences among treatments.
Population densities of Pythium spp. in soil averaged only $0.4 \mathrm{CFU} / \mathrm{g}$ in April and $7.3 \mathrm{CFU} / \mathrm{g}$ in September of the first year. However, in later years, population densities were high (50 to $276 \mathrm{CFU} / \mathrm{g}$ ) in the spring and variable ( 3 to $53 \mathrm{CFU} / \mathrm{g}$ ) in the late summer. There were no differences among the rotations at any sampling. $P$. irregulare was identified most often in the spring (30 to $60 \%$ ), and in the late summer $P$. aphanidermatum $(17 \%)$ and $P$. irregulare (13\%) were identified most often from soil dilution plates. Other isolates were not identified to species.

Nematodes. Root-knot nematodes were found more frequently in soil assays than were other plant-parasitic nematodes. $M$. incognita population densities were low during 1990, and not different in bahiagrass compared with vegetables (Table 3 ). In 1991 and 1992, population densities were lower in bahiagrass than in continuous vegetables at midseason and late-season sampling dates (and 16 July 1993), but numbers of $M$. incognita were not lower $(P$ $=0.05)$ in vegetables following bahiagrass
1, 2, or 3 years except 16 July 1993. The root-gall indices of cucumber and snap bean were not reduced following 1 year of bahiagrass, but 2 and 3 years of bahiagrass reduced the root-gall indices on both crops (Table $4, P=0.05$ ). The effects of bahiagrass in rotation lasted only 1 year, and after that, the $M$. incognita population densities in soil at most sampling dates and the root-gall indices of cucumber and snap bean were similar in bahiagrass rotations and in continuous vegetables.

Yield. Grazing by deer reduced yield in cucumber the first year, but not thereafter. Yellow nutsedge increased each year in continuous vegetables, and competition with yellow nutsedge was particularly deleterious to snap bean in the last 2 years. Population densities of yellow nutsedge and other weeds were low for 1 to 2 years following bahiagrass.

Cucumber and snap bean yields were increased $(P=0.05)$ after 3 years of bahiagrass, but not after 1 or 2 years of bahiagrass, compared with continuous vegetable production (Table 5). In the final year,

Table 3. Population densities of Meloidogyne incognita second-stage juveniles (J2) in soil in vegetable-bahiagrass rotations, 1990 to 1993

\begin{tabular}{|c|c|c|c|c|c|c|c|c|c|c|c|c|}
\hline \multirow[b]{3}{*}{ Rotation $^{y}$} & \multicolumn{12}{|c|}{ M. incognita juveniles $/ 150 \mathrm{~cm}^{3}$ of soil } \\
\hline & \multicolumn{3}{|c|}{1990} & \multicolumn{3}{|c|}{1991} & \multicolumn{3}{|c|}{1992} & \multicolumn{3}{|c|}{1993} \\
\hline & $10 \mathrm{Apr}$ & 6 July & 29 Oct & $18 \mathrm{Apr}$ & 26 June & 10 Dec & 17 Mar & 14 July & 3 Sep & 20 Apr & 16 July & 27 Sep \\
\hline $\mathrm{V}-\mathrm{V}-\mathrm{V}-\mathrm{V}$ & $4 a^{z}$ & $20 \mathrm{a}$ & $10 \mathrm{ab}$ & $26 \mathrm{a}$ & $38 \mathrm{a}$ & $1,008 \mathrm{a}$ & $184 \mathrm{~b}$ & $210 \mathrm{~b}$ & $444 \mathrm{a}$ & $40 \mathrm{a}$ & $974 \mathrm{a}$ & $66 \mathrm{a}$ \\
\hline B-V-V-V & $8 \mathrm{a}$ & $26 \mathrm{a}$ & $10 \mathrm{ab}$ & $4 \mathrm{a}$ & $30 \mathrm{ab}$ & $640 a b$ & $598 \mathrm{a}$ & $496 \mathrm{a}$ & $412 \mathrm{a}$ & $46 \mathrm{a}$ & 558 a & $78 \mathrm{a}$ \\
\hline B-B-V-V & $4 \mathrm{a}$ & $20 \mathrm{a}$ & $2 \mathrm{~b}$ & $4 \mathrm{a}$ & $0 \mathrm{c}$ & $18 \mathrm{~b}$ & $8 \mathrm{~b}$ & $60 \mathrm{bc}$ & $208 \mathrm{ab}$ & $88 \mathrm{a}$ & $470 a b$ & $88 \mathrm{a}$ \\
\hline B-B-B-V & $0 \mathrm{a}$ & $26 \mathrm{a}$ & $20 \mathrm{a}$ & $18 \mathrm{a}$ & $12 \mathrm{a}-\mathrm{c}$ & $4 \mathrm{~b}$ & $0 \mathrm{~b}$ & $6 \mathrm{c}$ & $52 \mathrm{~b}$ & $20 \mathrm{a}$ & $18 \mathrm{~b}$ & $38 \mathrm{a}$ \\
\hline
\end{tabular}

x Samples in March and April were before planting vegetables, samples in June and July were after cucumber was harvested, and samples in September to December were after snap bean was harvested.

${ }^{\text {y }} \mathrm{V}=$ vegetables, $\mathrm{B}=$ bahiagrass. Each entry separated by a hyphen denotes a 1-year period.

${ }^{\mathrm{z}}$ Numbers within columns followed by the same letter are not significantly different according to $t$ tests (Fisher's LSD), $P=0.05$.

Table 4. Root-gall indices on cucumber and snap bean in vegetable-bahiagrass rotations, 1990 to 1993

\begin{tabular}{|c|c|c|c|c|c|c|c|c|}
\hline \multirow[b]{3}{*}{ Rotation $^{x}$} & \multicolumn{8}{|c|}{ Root-gall index ${ }^{w}$} \\
\hline & \multicolumn{2}{|c|}{1990} & \multicolumn{2}{|c|}{1991} & \multicolumn{2}{|c|}{1992} & \multicolumn{2}{|c|}{1993} \\
\hline & $\mathrm{Cuc}^{\mathrm{y}}$ & $\mathbf{S B}^{\mathbf{y}}$ & Cuc & SB & Cuc & SB & Cuc & SB \\
\hline V-V-V-V & 2.4 & 2.2 & $4.4 a^{z}$ & $3.5 \mathrm{a}$ & $4.5 \mathrm{a}$ & $4.4 \mathrm{a}$ & $4.5 \mathrm{a}$ & $3.4 \mathrm{a}$ \\
\hline B-V-V-V & $\ldots$ & $\ldots$ & $4.7 \mathrm{a}$ & $3.9 \mathrm{a}$ & $5.0 \mathrm{a}$ & $4.1 \mathrm{a}$ & $4.4 \mathrm{a}$ & $3.9 \mathrm{a}$ \\
\hline B-B-V-V & $\ldots$ & $\ldots$ & $\ldots$ & $\ldots$ & $2.8 \mathrm{~b}$ & $2.8 \mathrm{~b}$ & $4.1 \mathrm{a}$ & $3.4 \mathrm{a}$ \\
\hline B-B-B-V & $\ldots$ & $\ldots$ & $\ldots$ & $\ldots$ & $\ldots$ & $\ldots$ & $2.5 \mathrm{~b}$ & $2.2 \mathrm{~b}$ \\
\hline
\end{tabular}

${ }^{\text {w }}$ Root-gall index based on scale of 1 to $5: 1=$ no galling, $2=1$ to $25,3=26$ to $50,4=51$ to 75 , and $5=76$ to $100 \%$ of roots galled after harvesting was completed.

${ }^{x} \mathrm{~V}=$ vegetables, $\mathrm{B}=$ bahiagrass. Each entry separated by a hyphen denotes a 1-year period.

${ }^{y} \mathrm{Cuc}=$ cucumber, $\mathrm{SB}=$ snap bean.

${ }^{\mathrm{z}}$ Numbers within columns followed by the same letter are not significantly different according to $t$ tests (Fisher's LSD), $P=0.05$.

Table 5. Yield of cucumber and snap bean in vegetable-bahiagrass rotations, 1990 to 1993

\begin{tabular}{|c|c|c|c|c|c|c|c|c|}
\hline \multirow[b]{2}{*}{ Rotation $^{w}$} & \multicolumn{2}{|c|}{1990} & \multicolumn{2}{|c|}{1991} & \multicolumn{2}{|c|}{1992} & \multicolumn{2}{|c|}{1993} \\
\hline & $\mathrm{Cuc}^{\mathrm{x}}$ & SB $^{\mathbf{y}}$ & Cuc & SB & Cuc & SB & Cuc & SB \\
\hline $\mathrm{V}-\mathrm{V}-\mathrm{V}-\mathrm{V}$ & 17,717 & 7,560 & 12,919 & 2,076 & 18,487 & 1,117 & $2,055 \mathrm{~b}^{\mathrm{z}}$ & $103 \mathrm{~b}$ \\
\hline B-V-V-V & $\ldots$ & $\ldots$ & 18,784 & 1,848 & 17,362 & 997 & $1,874 \mathrm{~b}$ & $176 \mathrm{~b}$ \\
\hline B-B-V-V & $\ldots$ & $\ldots$ & $\ldots$ & $\ldots$ & 16,364 & 3,740 & $12,739 \mathrm{a}$ & $363 \mathrm{~b}$ \\
\hline B-B-B-V & $\ldots$ & $\ldots$ & $\ldots$ & $\ldots$ & $\ldots$ & $\ldots$ & $25,836 \mathrm{a}$ & $1,393 \mathrm{a}$ \\
\hline
\end{tabular}

${ }^{\mathrm{w}} \mathrm{V}=$ vegetables, $\mathrm{B}=$ bahiagrass. Each entry separated by a hyphen denotes a 1-year period.

${ }^{x} \mathrm{Cuc}=$ cucumber fruits, $\mathrm{kg} / \mathrm{ha}$.

y $\mathrm{SB}=$ snap bean green pods, $\mathrm{kg} / \mathrm{ha}$.

${ }^{\mathrm{z}}$ Numbers followed by the same letter are not different according to $t$ tests (Fisher's LSD), $P=0.05$. No letters indicates no significant differences. 
yield of cucumber following 2 years bahiagrass-1 year vegetables was comparable to following 3 years of bahiagrass. Poor pollination because of low numbers of bees may have lowered the yield of marketable cucumber fruit during the last 2 years.

\section{DISCUSSION}

Three years of bahiagrass in rotation with vegetables will reduce root diseases and root galling induced by soilborne pathogenic fungi and root-knot nematodes and increase marketable yield of vegetables. In some instances, 2 years of bahiagrass reduced injury from soilborne pathogenic fungi and root-knot nematodes. Average yield of cucumber following bahiagrass always exceeded the average yield in Georgia (7). Snap bean yield was above the state average in the first year, but the best yield in subsequent years was below the state average. In Alabama, a 2-year rotation with bahiagrass produced greater yield of sweet potato (Ipomoea batatas) than rotations with soybean or sweet corn (8). In Florida, watermelon yields were greater and Fusarium wilt was reduced after 3 years of bahiagrass compared with continuous watermelon (10). In rotation with coastal bermudagrass, okra (Abelmoschus esculentus) and squash (Cucurbita реро) yields were greater following 2 or 3 years of sod than following 1 year of sod or fallow (15). In another rotation with coastal bermudagrass, yields of snap bean, pepper (Capsicum annuum), and okra did not differ $(P=0.05)$ between fallow and 1 year of sod, but yields of all vegetable crops were greater following 3 years of sod than following fallow (14). Snap bean, cucumber, and sweet potato were grown following 4 years of coastal bermudagrass sod with good yields and no visible injury from root-knot nematodes or soilborne pathogenic fungi (32). The effects of bahiagrass and coastal bermudagrass appear to be nonspecific, as both grasses in rotation for 2 to 4 years reduced root disease severity and root galling in vegetables. Other grasses in long rotations with vegetables may have similar beneficial effects in improving root health.

In this research, population densities of $R$. solani AG-4 usually were low because conventional tillage with a moldboard turning plow was used before planting each crop. If conservation tillage had been used, the rotations with bahiagrass may have been even more beneficial in keeping inoculum of $R$. solani AG-4 at low levels (25). Inoculum densities of $R$. solani AG4 in the surface soil are directly related to the frequency of belly rot in cucumber (30) and root and hypocotyl rot in snap bean (31). When fallow and coastal bermudagrass sod plots were disk-harrowed and plowed 15 to $25 \mathrm{~cm}$ deep with a moldboard plow, population densities of Pythium spp. and $R$. solani AG-4 in soil after planting vegetables were suppressed by 2 or 3 years of sod compared with fallow (14).

These experiments were not designed to determine the influence of rotation on weed control, but the increase of yellow nutsedge with time in continuous vegetable production was obvious. In contrast, population densities of yellow nutsedge were low following 2 to 3 years of bahiagrass. A similar increase in yellow nutsedge was observed in other experiments with a continuous vegetable rotation (16). In vegetables following coastal bermudagrass sod rotations, yellow nutsedge declined (14).

This research shows that less than 2 years of bahiagrass will probably have negligible effect on reducing soil pests and that the beneficial effects of rotation only last through one double-crop. Because of the expense of establishing bahiagrass sod, rotations probably will work best for diversified vegetable growers who have livestock or hay operations. The environmental benefits of reduced usage of soil pesticides may be more important to growers in some areas than in others. Home gardeners and vegetable growers with limited production who can establish a rotation of 2 years or more with bahiagrass should be able to produce acceptable yields of quality vegetables without using soil pesticides.

\section{ACKNOWLEDGMENTS}

This research was supported by state, Hatch, and USDA Agricultural Research Service funds allocated to the Georgia Agricultural Experiment Station. No endorsements are implied herein. Appreciation is expressed to Ben Mullinix for assistance with statistical analysis.

\section{LITERATURE CITED}

1. Baird, R. E., Brenneman, T. B., Bell, D. K., Sumner, D. R., Minton, N. A., Mullinix, B. G., and Peery, A. B. 1996. Influence of crop rotation and flutolanil on the diversity of fungi in peanut shells. Phytoprotection 76:101-113.

2. Brenneman, T. B., Sumner, D. R., Baird, R. E., Burton, G. W., and Minton, N. A. 1995. Suppression of foliar and soilborne peanut diseases in bahiagrass rotations. Phytopathology 85:948-952.

3. Burton, G. W., and Johnson, A. W. 1987. Coastal bermudagrass rotations for control of root-knot nematodes. J. Nematol. 19:138-140.

4. Dickson, D. W., and Hewlett, T. E. 1989. Effects of bahiagrass and nematicides on Meloidogyne arenaria on peanut. J. Nematol. 21:671-676.

5. Dunn, R. A. 1988. Nematode pests of watermelons and cantaloupes. Nematology Plant Protection Pointer. No. 24. University of Florida, IFAS.

6. Evert, D. R., and Bertrand, P. F. 1993. Survival and growth of peach trees planted in killed bahiagrass at an old orchard site. HortScience 28:26-28.

7. Georgia Agricultural Statistics Service. 1996. Georgia Agricultural Facts. Georgia Agricultural Statistics Service, Athens.

8. Guertal, E. A., Bauske, E. M., and Edwards, J. H. 1997. Crop rotation effects on sweet potato yield and quality. J. Prod. Agric. 10:70-73.

9. Henis, Y., Ghaffar, A., Baker, R., and Gillespie, S. L. 1978. A new pellet soil-sampler and its use for the study of population dynamics of Rhizoctonia solani in soil. Phytopathology 68:371-376.

10. Hopkins, D. L., and Elmstrom, G. W. 1984. Effect of nonhost crop plants on watermelon Fusarium wilt. Plant Dis. 68:239-241.

11. Jeffers, S. N., and Martin, S. B. 1986. Comparison of two media selective for Phytophthora and Pythium species. Plant Dis. 70:1038-1043.

12. Jenkins, W. R. 1964. A rapid centrifugalflotation technique for separating nematodes from soil. Plant Dis. Rep. 48:692.

13. Johnson, A. W. 1998. Vegetable crops. Pages 595-635 in: Plant Nematode Interactions. K R. Barker, G. A. Pederson, and G. L. Windam, eds. American Society of Agronomy, Madison, WI.

14. Johnson, A. W., Burton. G. W., Sumner, D. R., and Handoo, Z. 1997. Coastal bermudagrass rotation and fallow for management of nematodes and soilborne fungi on vegetable crops. J. Nematol. 29(4S):710-716.

15. Johnson, A. W., Burton, G. W., Wilson, J. P., and Golden, A. M. 1995. Rotations with coastal bermudagrass and fallow for management of Meloidogyne incognita and soilborne fungi on vegetable crops. J. Nematol. 27:457-464.

16. Johnson, A. W., Dowler, C. C., Glaze, N. C., and Sumner, D. S. 1983. Effects of intensive cropping systems and pesticides on nematodes and crop yields. U.S. Dep. Agric., Agric. Res. Serv., Results, ARR-S-14.

17. Norden, A. J., Perry, V. G., Martin, F. G., and NeSmith, J. 1980. Effect of age of bahiagrass sod on succeeding corn crops. Soil Crop Sci. Soc. Fla. Proc. 39:118-121.

18. Rodriguez-Kabana, R., Kokalis-Burelle, N., Roberton, D. G., King, P. S., and Wells, L. W. 1994. Rotations with coastal bermudagrass, cotton, and bahiagrass for management of Meloidogyne arenaria and southern blight in peanut. Suppl. J. Nematol. 26:665-668.

19. Rodriguez-Kabana, R., Robertson, D. G., Weaver, C. F., and Wells, L. 1991. Rotations of bahiagrass and castorbean with peanut for the management of Meloidogyne arenaria. Suppl. J. Nematol. 23:658-661.

20. Rodriguez-Kabana, R., Weaver, D. B., Garcia, R., Robertson, D. G., and Carden, E. L. 1989. Bahiagrass for the management of root-knot and cyst nematodes in soybean. Nematropica 19:185-193.

21. Rodriguez-Kabana, R., Weaver, D. B., Robertson, D. G., Carden, E. L., and Pegues, M L. 1991. Additional studies on the use of bahiagrass for the management of root-knot and cyst nematodes in soybean. Nematropica 21:203-210.

22. SAS Institute. 1985. SAS Users Guide: Statistics. Ver. 5th ed. SAS Institute, Cary, NC.

23. Steel, R. G. D., and Torrie, J. H. 1960. Principles and Procedures of Statistics. McGrawHill Book Co., New York.

24. Sumner, D. R., and Bell, D. K. 1982. Root diseases of corn induced by Rhizoctonia solani and Rhizoctonia zeae. Phytopathology 72:86-91

25. Sumner, D. R., Doupnik, B., Jr., and Boosalis, M. G. 1981. Effects of reduced tillage and multiple cropping on plant diseases. Annu. Rev. Phytopathol. 19:167-187.

26. Sumner, D. R., Dowler, C. C., Johnson, A. W., and Baker, S. H. 1995. Conservation tillage and seedling diseases in cotton and soybean double-cropped with triticale. Plant Dis. 79:372-375.

27. Sumner, D. R., Dowler, C. C., Johnson, A. W., Glaze, N. C., Phatak, S. C., Chalfant, R. B., and Epperson, J. E. 1983. Root diseases of cucumber in irrigated, multiple-cropping system with pest management. Plant Dis. 
67:1071-1075

28. Sumner, D. R., Johnson, A. W., Glaze, N. C., and Dowler, C. C. 1978. Root diseases of snapbean and southern pea in intensive cropping systems. Phytopathology 68:955-961.

29. Sumner, D. R., Phatak, S. C., Gay, J. D., Chalfant, R. B., Brunson, K. E., and Bugg, R. L. 1995. Soilborne pathogens in a vegetable dou- ble-crop with conservation tillage following winter cover crops. Crop Prot. 14:495-500.

30. Sumner, D. R., and Smittle, D. 1976. Etiology and control of fruit rot of cucumber in single harvesting for pickles. Plant Dis. Rep. 60:304-307.

31. Sumner, D. R., Smittle, D. A., Threadgill, E. D., Johnson, A. W., and Chalfant, R. B. 1986.
Interactions of tillage and soil fertility with root diseases in snap bean and lima bean in irrigated multiple-cropping systems. Plant Dis. 70:730-735.

32. Ukkelberg, H. G., and Harmon, S. A. 1966 Vegetable production on coastal bermudagrass sod. Univ. Ga. Agric. Exp. Stn Mimeogr. Ser. N.S. 243. 